UDK 341.231.14:341.43

Original scientific paper

\title{
RESPONSIBILITY FOR HUMAN RIGHTS VIOLATIONS OF PRIVATE MILITARY AND SECURITY COMPANIES ON EU BORDERS: A CASE STUDY OF THE CONTRACTS OF THE EUROPEAN ASYLUM SUPPORT OFFICE*
}

\author{
Bence Kis Kelemen, LLM, assistant lecturer \\ University of Pécs, Faculty of Law, \\ Department of International and European Law \\ H-7622 Pécs, 48-as tér 1. \\ kis.kelemen.bence@ajk.pte.hu
}

\begin{abstract}
The present contribution addresses the question of attribution of private conduct to international organizations, more specifically whether the conduct of private military and security companies can be equated with that of the European Union in connection with migration and border control. The paper also incorporates the analysis of two contracts concluded between a private company and the European Asylum Support Office for provision of security services for the premises of the institution and for hotspots in Greece. The main findings of the paper are that while there are a number of ways to attribute the conduct of private entities to international organizations such as exercising elements of governmental authority or effective control over specific operations of private persons, there are inherent difficulties within the procedural aspects of proving such an attributional link. In addition to this, in spite of contrary scholarly opinion, this paper asserts that private military and security companies do not play a significant role in implementing the European Agenda on Migration, at least on the EU level. Conversely, the services they provide are not unique to migration control, but necessary for the effective operation of EASO. The attribution of the examined conduct is not possible through exercising elements of governmental authority, and proving effective control for a specific operation would also encounter considerable difficulties.
\end{abstract}

Keywords: private military and security companies, European Union, European Asylum Support Office, attribution, internationally wrongful acts

The present author would like to thank Ágoston Mohay (University of Pécs) for the fruitful discussions and excellent suggestions. The peresent contribution was made possible by the László János Research Scholarship awarded by the University of Pécs, and the Outstanding Scientific and Arts Scholarship awarded by the Doctoral Student Association of the University of Pécs 


\section{INTRODUCTION}

The European Union (hereinafter: EU or Union) has experienced an unprecedented number of asylum seekers and migrants coming from various locations from the Middle East and Africa. Some refer to this increase in migration as the 'Migration Crisis of 2015'. ${ }^{1}$ The Union's asylum system has been under heavy pressure ever since, which revealed the inherent weaknesses within the system. ${ }^{2}$ Attempting to find a solution to the difficulties arisen, EU has adopted legal instruments, ${ }^{3}$ struck international agreements such as the EU-Turkey deal ${ }^{4}$ and created the European Agenda on Migration. ${ }^{5}$ Daria Davitti in her excellent analysis on the subject claims that this document is shaped and implemented by private military and security companies (hereinafter: PMSCs). ${ }^{6}$

For the purposes of the present contribution, PMSCs are defined as "private business entities that provide military and/or security services, irrespective of how they describe themselves. Military and security services include, in particular, armed guarding and protection of persons and objects, such as convoys, buildings and other places; maintenance and operation of weapons systems; prisoner detention; and advice to or training of local forces and security personnel." ${ }^{\prime 7}$ This definition is

1 Migrant crisis: One million enter Europe in 2015, BBC News, [https://www.bbc.com/news/world-europe-35158769], Accessed 13 April 2020. See also Henley J., What is the current state of the migration crisis in Europe? The Guardian, [https://www.theguardian.com/world/2018/jun/15/what-currentscale-migration-crisis-europe-future-outlook], Accessed 13 April 2020

2 Beirens H., Cracked Foundation, Uncertain Future - Structural weaknesses in the Common European Asylum System, Migration Policy Institute Europe, [https://www.migrationpolicy.org/sites/default/files/ publications/CEAS-StructuralWeaknesses_Final.pdf], Accessed 13 April 2020

3 E.g. Regulation (EU) No 604/2013 of the European Parliament and of the Council of 26 June 2013 establishing the criteria and mechanisms for determining the Member State responsible for examining an application for international protection lodged in one of the Member States by a third-country national or a stateless person [2013] OJ L 180, 29.6.2013, p. 31 - 59

4 See Agreement between the European Union and the Republic of Turkey on the readmission of persons residing without authorization, [2014] OJ L 134, 7.5.2014, p. 3 - 27. Although it needs to be mentioned that this 'deal' has no stable footing in contemporary international relations. Recep Tayyip Erdoğan Turkish president 'encouraged' thousands of refugees currently living in Turkey to move towards Europe. The incident ended with the EU providing financial support for the regime of Erdoğan. See Wintour P.; Smith H.: Erdoğan in talks with European leaders over refugee cash for Turkey, The Guardian. [https://www.theguardian.com/world/2020/mar/17/erdogan-in-talks-with-europeanleaders-over-refugee-cash-for-turkey], Accessed 13 April 2020

5 Communication from the Commission to the European Parliament, the Council, The European Economic and Social Committee and the Committee of the Regions - A European Agenda on Migration, $\operatorname{COM}(2015)$ 240, Brussels, 13 May 2015

6 Davitti, D., The Rise of Private Military and Security Companies in European Union Migration Policies: Implications under the UNGPs, Business and Human Rights Journal, vol. 4, no. 1, 2018, pp. $37-42$

7 The Montreux Document on pertinent international legal obligations and good practices for States related to operations of private military and security companies during armed conflict, 2008, Preface 9. a) 
provided by the so-called 'Montreaux Document' from 2008 that was created on the initiative of Switzerland and the International Committee of the Red Cross in cooperation with 17 states, non-governmental organization, the industry as well as academic circles. This document is a collection of soft law, good practices as well as customary international law considered to be binding on states. ${ }^{8}$ It needs to be mentioned that no universally accepted definition for PMSCs can be identified, although various attempts to describe these businesses appear in the works of commentators as well as in international documents. ${ }^{10}$

PMSCs usually appear in academic articles in connection with international humanitarian law. ${ }^{11}$ This is in line with the most significant use of PMSCs, which customarily occurs in the context of armed conflicts ${ }^{12}$ and in peace-keeping operations. ${ }^{13}$ In the same vein, the use of PMSCs in the EU were mainly restricted to the

$8 \quad$ ibid. p. 31

9 Szalai, A., A katonai magánvállalatok részvétele és jogállása a fegyveres konfliktusokban, FÖLDrész Nemzetközi és Európai Jogi Szemle, vol. 3, no. 1 - 2, 2010, p. 38

10 The 'tone' of the definition might be tailored in light of services these businesses prove. For scholarship see See e.g. Cameron, L.; Chetail, V., Privatizing War - Private Military and Security Companies under Public International Law, Cambridge University Press, Cambridge, New York, 2013, pp. 1 - 2 or Janaby, M. G., The Legal Regime Applicable to Private Military and Security Company Personnel in Armed Conflicts, Springer, Cham, 2016, pp. 1 - 4. For international documents see e.g. International Code of Conduct for Private Security Service Providers, 9 November 2010, which is a code of conduct for business enterprises, who voluntary choose to follow the rules laid down within the document. For another definition, see Article 2 of the Draft Convention on Private Military and Security Companies (PMSCs) for consideration and action by the Human Rights Council, Report of the Working Group on the use of mercenaries as a means of violating human rights and impeding the exercise of the right of peoples to self-determination, A/HRC/12/25, 5 July 2010

11 See e.g. Schmitt, M. N., Humanitarian Law and Direct Participation in Hostilities by Private Contractors or Civilian Employees, Chicago Journal of International Law, vol. 5, no. 2, 2005, pp. 511 - 546. del Prado, J. L. G., The Ineffectiveness of the Current Definition of a "Mercenary" in International Humanitarian and Criminal Law, in: Torroja, H. (ed.), Public International Law and Human Rights Violations by Private Military and Security Companies, Springer, Cham, 2017, pp. 59 - 81. Foong, A., The Privatization of War: From Privateers and Mercenaries to Private Military and Security Companies, Asia Pacific Yearbook of International Humanitarian Law, vol. 4, 2008 - 2011, pp. $210-244$. When it comes to armed conflicts, the question arises whether there is a connection between PMSCs and mercenaries. The International Convention against the Recruitment, Use, Financing and Training of Mercenaries, 4 December 1989. determines in Article 1 who can be considered to be a mercenary. Based on the criteria the present paper argues, that the criteria for mercenaries is too narrow to incorporate all members of PMSCs. However, in some cases there can be an overlap between the two categories, which could have serious legal consequences for the state employing a PMSCs

12 On the conduct of non-state actors such as PMSCs in Afghanistan and Syria see e.g. Laborie, M., Afghanistan and Syria: Nonstate Actors and Their Negative Impact on Human Security, in: Torroja, H. (ed.), Public International Law and Human Rights Violations by Private Military and Security Companies, Springer, Cham, 2017, pp. 7 - 29

13 Crowe, J.; John, A., The Status of Private Military Security Companies in United Nations Peacekeeping Operations under the International Law of Armed Conflict, Melbourne Journal of International Law, vol. 
protection of EUPOL headquarters in Afghanistan, the mission in the Democratic Republic of Congo, and the EULEX mission in Kosovo. ${ }^{14}$ On the other hand, PMSCs also appeared in another context in the last two decades, namely migration and border control. The company G4S for example has been contracted to be involved in border control along the United States - Mexico border. The same company was commissioned with running detention facilities by Australia. The United Kingdom also made a contract with G4S for the annual transfer of asylum seekers between detention and removal facilitates and the operation of such centers. ${ }^{15}$ PMSCs also appeared in connection with EU research projects as well, namely the European External Border Surveillance System (EUROSUR) and Frontex's (European Border and Coast Guard Agency) drone workshops. ${ }^{16}$ Litigation in Australia in connection with alleged human rights violations in PMSCs run detention centers ${ }^{17}$ and the intertwining of PMSCs with the European Agenda on Migration [most prominently contracts that had been concluded between G4S and the European Asylum Support Office (hereinafter: EASO)] and the activities of some Member States led a number of commentators to believe that the EU might also be engaged in a similar outsourcing of border and migration control to PMSCs; suggesting that such business relations are in place ${ }^{18}$ and alleged interference with rights of asylum seekers in connection with this phenomenon has already emerged. ${ }^{19}$

In case the Union outsources border and migration related activities to PMSCs, an important question arises: namely, who will be responsible for the conduct of such business enterprises? This contribution examines the responsibility of international organizations for internationally wrongful acts in connection with attribution of private conduct (Part II). In turn, the paper will analyze whether the EU indeed outsources such activities. The paper will look into the contracts concluded between EASO and G4S which will shed light on the true nature of such

18 , no. 1,2017 , pp. $16-44$

14 European Parliament: The Role of private security companies (PSCs) in CSDP missions and operations. Directorate-General for External Policies of the Union, Directorate B, Policy Department, 2011

15 Lemberg-Pedersen, M., Private security companies and the European borderscapes, in: Gammeltoft-Hansen, T.; Nyberg, N. (eds.), The Migration Industry and the Commercilizations of International Migration, Routledge, London, 2013, pp. 154, 156

16 ibid. p. $156-157,165$

17 Kamasaee v Commonwealth of Australia \& Ors (Approval of settlement) [2017] VSC 537. For an analysis see Holly, G., Transnational Tort and Access to Remedy under the UN Guiding Principles on Business and Human Rights: Kamasaee v Commonwealth, Melbourne Journal of International Law, vol. 19, no. 1, 2018, pp. $52-83$

18 Davitti, op. cit., note 6, pp. 41 and 50. Lemberg-Pedersen, op. cit., note 15, p. 166

19 Lethbridge, J., Privatisation of Migration and Refugee Services and Other Forms of State Disengagement, Public Services International [http://www.world-psi.org/en/privatisation-migration-refugee-services-other-forms-state-disengagement], Accessed 13 April 2020 
agreements and investigates the alleged human right violations that had occurred within the framework of this contract (Part III). Finally, the paper concludes that contemporary outsourcing of border and migration control cannot be determined on a factual basis on behalf of the EU: only providing security services for Union staff can be identified, which is necessary for every public institution to operate efficiently, and is hardly unique to migration or border control. This leaves the examination of attribution of PMSCs' conduct committing serious human rights violations merely a theoretical exercise, the results can however, be used in other areas as well. In the meantime, regulation might be required at the EU level for contracting PMSCs - and even though at the time of writing this is most prominent in the context of the Common Foreign and Security Policy, in case there will be a shift of policy within border and migration control, the same legislation could also become relevant in the Area of Freedom, Security and Justice (Part IV).

\section{RESPONSIBILITY OF INTERNATIONAL ORGANIZATIONS FOR INTERNATIONALLY WRONGFUL ACTS}

This part of the analysis will serve as an introduction to the responsibility of international organizations for internationally wrongful acts. The basis of the examination is a hypothetical scenario in which a private company, namely a PMSC hired by an international organization, the European Union, is committing a human rights violation. There are two possible avenues liability can take. The first is when the private conduct is indeed attributable to the international organization (Section 1.). The second road responsibility can take is through the positive obligations stemming from international human rights law, ${ }^{20}$ which is outside of the scope of the present analysis, for it requires further thorough research. Before elaborating on the issues presented above, a clarification is required for methodological purposes. The present contribution stands on the basis of positive law, therefore soft law instruments, such as the United Nations Guiding Principles on Business and Human Rights ${ }^{21}$ and operational level grievance mechanisms ${ }^{22}$ thus fall beyond the scope of this analysis.

20 On the subject see e.g. Xenos, D., The Positive Obligations of the State under the European Convention of Human Rights, Routledge, London, New York, 2012

21 United Nations Guiding Principles on Business and Human Rights: Implementing the United Nations 'Protect, Respect and Remedy' Framework (A/HRC/17/31) adopted by the Human Rights Council on 16 June 2011 as resolution 17/4. Two examination of issues related to this document and the activities of PMSCs was provided by Daria Davitti See. Davitti, op. cit., note 6, pp. 42 - 53. and Davitti, D., Beyond the Governance Gap: Accountability in Privatized Migration Control, German Law Journal, vol. 21, no. 3, 2020, pp. $3-16$

22 Wallace, S., Case Study on Holding Private Military and Security Companies Accountable for Human Rights Violations, Frame. Work Package No. 7. - Deliverable No. 7.5. 2016, pp. 16 - 28 
The European Union is a supranational community, ${ }^{23}$ yet it is still an international organization, governed primarily by two international treaties, the Treaty on the European Union ${ }^{24}$ (hereinafter: TEU) and the Treaty on the Functioning of the European Union ${ }^{25}$ (hereinafter: TFEU). The EU has not (or at least not yet) reached a phase in its development to become a federal state such as the United States of America. The responsibility of the EU as an international organization is regulated by customary international law. A compilation of these rules can be found in the Draft Articles on the responsibility of international organizations (hereinafter: DARIO), prepared by the United Nations' International Law Commission ${ }^{26}$ and adopted by the General Assembly in 2011. ${ }^{27}$ Although DARIO is not as widely accepted as its counterpart, the Draft Articles on responsibility of states for internationally wrongful acts (hereinafter: DARSIWA) ${ }^{28}$ some rules of it are without doubt considered to be of customary international law character. ${ }^{29}$ The European Union, through one of its institutions, the European Commission on the other hand expressed its concerns regarding DARIO, since the EU believed that DARIO does not take into account the specificities of the Union. ${ }^{30}$ The European Commission in a general comment to DARIO due to the high impact of the proposed rules to the EU, stated, that

"[f] or now, the EU remains unconvinced that the draft articles and the commentaries thereto adequately reflect the diversity of international organizations. Several draft articles appear either inadequate or even inapplicable to regional integration organizations such as the EU, even when account is taken of some of the nuances now set out in the commentaries. In addition, some commentaries show that there is very little or no relevant practice to support the suggested provisions." 31

23 Chalmers, D.; Davies, G.; Monti, G., European Union Law, Second edition, Cambridge University Press, Cambridge, New York, 2010, p. 14

24 TEU (Lisbon)

25 TFEU (Lisbon)

26 Adopted by the International Law Commission at its sixty-third session, in 2011, and submitted to the General Assembly as a part of the Commission's report covering the work of that session (A/66/10)

27 Resolution adopted by the General Assembly on 9 December 2011 66/100. Responsibility of international organizations. (A/RES/66/100)

28 Resolution adopted by the General Assembly on 12 December $200156 / 83$. Responsibility of States for internationally wrongful acts. (A/RES/56/83)

29 Mölder, M., Responsibility of International Organizations - Introducing the ILC's Dario, in: von Bogdandy, A.; Wolfrum, R. (eds.), Max Planck Yearbook of United Nations Law, vol. 16, 2012, p. 286

30 Responsibility of international organizations. Comments and observations received from international organizations dated 14 and 17 February 2011 (A/CN.4/637 and Add.1.). p. 138. European Commission para 1

31 ibid. p. 138. European Commission, para. 2 
Commentators also expressed concerns regarding the customary international law status of the rules enshrined in DARIO. ${ }^{32}$ This paper however uses specific rules of DARIO in order to examine violations of international law and attribution of conduct to the EU. Article 4 of DARIO, which sets out the elements of an internationally wrongful act of an international organization is essentially identical with that applicable to states, ${ }^{33}$ which should be accepted as customary international law applicable to the EU since no comment has been made to that particular article. Article 5 on the characterization of an act as internationally wrongful however received sharp criticism from the Union since the internal laws of the EU should be differentiated from international law. ${ }^{34}$ The International Law Commission on the other hand has addressed the critique in the commentaries to DARIO expressis verbis recognizing the special views of the Court of Justice of the European Union, declaring that " $[\mathrm{b}]$ reaches of obligations under the rules of the organization are not always breaches of obligations under international law." 35 Consequently, it is logical to conclude that the general rules on violating international law can be identified through DARIO even for the purposes of the EU. The only problem that can arise stems from the Charter of Fundamental Rights of the European Union, which since the Lisbon Treaty has the same legal 'value' as the fundamental treaties. ${ }^{36}$ As for attribution, the European Commission's comment regarding the term 'agent' - namely the need to define $\mathrm{it}^{37}$ - has been accepted by the International Law Commission resulting in Article 2(d) of DARIO, furthermore the International Court of Justice has already posited the core content of the articles referred to in this paper in several advisory opinions. ${ }^{38}$ Due to this, the contribution accepts Sari and Wessel's position that "no special considerations justify the application of lex specialis rules of attribution" ${ }^{39}$ to the Union's conduct. In

32 See e.g. Bordin, F. L., Reflections of customary international law: the authority of codification conventions and ILC draft articles in international law, International Comparative Law Quarterly, vol. 63, no. 3, 2014, pp. 556 - 557 and 560 - 561, pointing out that even the International Law Commissions considers a significant number of provisions within DARIO as progressive development, rather than codification

33 See Article 2 DARSIWA

34 Responsibility of international organizations. op. cit., note 30, pp. 146-147 paras 1-5

35 Draft articles on the responsibility of international organizations, with commentaries, Yearbook of the International Law Commission, vol. II, Part 2, 2011, p. 63. para 5. note 171. and p. 64. para 7

36 Article 6(1) TEU. This examination falls beyond the scope of the present contribution

37 Responsibility of international organizations. op. cit., note 30, p. 143

38 See eg. Reparations for injuries suffered in the service of the United Nations, Advisory Opinion: I.C.J. Reports 1949, p. 174. and Applicability of Article VI, Section 22, of the Convention on the Privileges and Immunities of the United Nations, Advisory Opinion, I.C.J. Reports 1989, p. 177

39 Sari. A.; Wessel, R. A., International Responsibility for EU Military Operations: Finding the EU's place in the Global Accountability Regime, in: Van Vooren, B.; Blockmans, S.; Wouters, J. (eds), The EU's Role in Global Governance: The Legal Dimension, Oxford University Press, Oxford, 2013, p. 129. 
other words, this paper argues that the general rules of attribution in accordance with DARIO is applicable to the European Union, no special rules or special treatment is granted for the EU.

According to Article 4 of DARIO, an internationally wrongful act is committed by an international organization, when conduct consisting of an action or an omission, that is attributable to the international organization constitutes a breach of an international obligation. ${ }^{40} \mathrm{~A}$ breach of an international obligation may occur regardless of the origin or character of the obligation concerned and for member states a breach may stem from a violation of the rules of the organization. ${ }^{41}$ In the following, the contribution addresses the issue of attribution of conduct to international organizations such as the EU.

\subsection{Attribution of conduct to the European Union}

This paper examines the conduct of PMSCs in the EU's migration and border activities, therefore it focuses on attribution of private conduct to international organizations, such as the EU. According to Article 6 of DARIO

" $[t]$ he conduct of an organ or agent of an international organization in the performance of functions of that organ or agent shall be considered an act of that organization under international law, whatever position the organ or agent holds in respect of the organization." ${ }^{2}$

Organs are defined by DARIO as persons or entities which have that status in accordance with the rules of the organization ${ }^{43}$ and agents as officials or other persons or entities, other than an organ, who are charged by the organization with helping to carry out or indeed carrying out one of their functions, in other words, through whom the organization acts. ${ }^{44}$ As for determining the functions of organs and agents, the rules of the organizations apply. ${ }^{45}$

Note that the originial quote refers to the EU crisis management missions within the context of the Common Foreign and Security Policy

40 Article 4 DARIO

41 Article 10 DARIO. According to Article 2 subparagraph (b) DARIO „"rules of the organization” means, in particular, the constituent instruments, decisions, resolutions and other acts of the international organization adopted in accordance with those instruments, and established practice of the organization"

42 Article 6, para. 1 DARIO

43 Article 2, supbaragraph (c) DARIO

44 Article 2, supbaragraph (d) DARIO

45 Article 6, para. 2 DARIO 
It can be observed that DARIO draws up the general rule of attribution to international organizations rather generously, linking the conduct of private individuals to the organizations. It should be noted that there are no separate articles for conduct of an organ of an international organization, or of persons or entities exercising element of governmental authority nor conduct which is directed or controlled by an international organization, rules which can be identified in DARSIWA, the counterpart of DARIO. ${ }^{46}$ The question arises whether these attributional links are indeed missing or whether they are enshrined in Article 6 of DARIO.

The commentary to DARIO denotes that a simpler wording was required for DARIO in order to capture the essence of the organs of international organizations. ${ }^{47}$ It is important to note that organs are not defined in the general attributional norm similarly to Article 4 of DARSIWA, DARIO rather gives a narrow definition to organs in Article 2(c), which can be equated with de jure organs of an international organization. De facto organs of an international organization on the other hand should be incorporated into the concept of 'agents' according to Article 2(d) of DARIO. This differentiation is crucial in light of the attribution. The conduct of a de jure organ of an international organization just as that of states would without doubt be attributable to the organization regardless of the level of control exercised over the de jure organ. ${ }^{48}$ To date no PMSC has ever been introduced as an organ of the European Union or to the knowledge of the present author of any other international organization. The same is however not true for states, which occasionally incorporate PMSCs into a state organ. ${ }^{49}$ The analysis therefore has to turn to de facto organs of an international organization, which are not designated as organs of the entity. The commentary to DARIO leaves the possibility open to exercise the functions of the international organization without the authorization of the rules of organization based on Article 6(1) of DARIO. ${ }^{50}$ The present contribution argues that such a function of the organization can be exercised through contracts concluded between the organization and a private entity or by creating such an 'agent'.

46 Article 4, 5 and 8 DARSIWA Other articles ar missing as well, namely Article 9 and 10. The present paper does not address the latter two questions since they are not applicable to international organizations nor to the factual issues of the contribution

47 Draft articles on the responsibility of international organizations, with commentaries, op. cit., note 35 , p. 56 , para. 8

48 Armed Activities on the Territory of the Congo (Democratic Republic of the Congo v. Uganda), Judgment, I.C.J. Reports 2005, p. 168, on p. 242. paras. $213-214$

49 Cameron; Chetail, op. cit., note 10, p. 141

50 Draft articles on the responsibility of international organizations, with commentaries, op. cit., note 35, p 56. para 9 and 11 
De facto organs of an international organization are therefore agents, which should have a rather liberal understanding, being able to incorporate paid or unpaid officials, individuals employed permanently or on a case-by-case basis, i.e. virtually anyone who is commissioned by the organization to carry out or help to carry out one or more of its functions. ${ }^{51}$ Having regard to the similar phenomenon in state responsibility, it is argued that the de facto organ should remain under 'complete dependency' of the international organization. ${ }^{52}$ Consequently, it can be concluded that it would be exceptionally hard to attribute the conduct of a PMSC to the $\mathrm{EU}$ or any other international organization on this basis. This route of attribution would only become relevant if the organization would create and own a PMSC while leaving them no room to retain any significant level of autonomy. ${ }^{53} \mathrm{Camer-}$ on and Chetail denote in the case of state-owned PMSCs that these organizations retain a considerable level of autonomy, which makes it impossible to use de facto organ attribution. ${ }^{54}$ The same should be true for international organization-owned PMSCs, if any exist at all.

According to the commentary to DARIO, another category of agents might be similar to exercising elements of governmental authority. Although the commentary stresses that it would be 'superfluous' to assign a separate article to this question such as Article 5 of DARSIWA, for on the one hand the terminology is not adequate for international organizations and on the other hand " $[\mathrm{t}]$ he term "agent" is given in subparagraph $(d)$ of article 2 a wide meaning that adequately covers these persons or entities." ${ }^{55}$ Exercising governmental authority along with direction and control considered by a number of scholars one of the practically possible scenarios for attribution in case of PMSCs conduct. ${ }^{56}$

51 Draft articles on the responsibility of international organizations, with commentaries, op. cit., note 35, p. 52. para 23

52 This test was first used by the International Court of Justice in the Nicaragua case, later reaffiremd in the Genocide case. See. Kis Kelemen, B.; van Rij, J., Private military and security companies on E.U. borders: who will take responsibility for their human rights violations? - A theoretical analysis, in: Kis Kelemen, B.; Mohay, Á., EU justice and home affairs research papers in the context of migration and asylum law, University of Pécs, Pécs, 2019, p. 101

53 A similar approach was taken by Cameron and Chetail, who propose a three-fold criteria for complete dependency: a) creation, b) cooperation with a significant involvment of the action of the PMSC and c) a low-level of autonomy. See Cameron; Chetail, op. cit., note 10, p. 149. For a critique of the general approach taken by Cameron and Chetail see Kis Kelemen; van Rij, op. cit., note 52, p. 103

54 Cameron; Chetail, ibid., p. 152

55 Draft articles on the responsibility of international organizations, with commentaries, op. cit., note 35 , p. 56 para 10

56 See for example. Davitti, op. cit., note 21, pp. 16 - 17 and 29. Tonkin, H., State Control over Private Military and Security Companies in Armed Conflict, Cambridge University Press, Cambridge, New York, 2011, pp. 99 -113. Kis Kelemen; van Rij, op. cit., note 52, p. 104 
Article 5 of DARSIWA posits that "[ $t$ ] he conduct of a person or entity which is not an organ of the State under article 4 but which is empowered by the law of that State to exercise elements of the governmental authority shall be considered an act of the State under international law, provided the person or entity is acting in that capacity in the particular instance." ${ }^{77}$ The commentary to DARSIWA expressly mentions privatization of public or regulatory functions. ${ }^{58}$ It is also denoted in the commentary that even a private corporation can be covered with the notion of 'entity', in case it is empowered by the law of the State to exercise governmental authority. ${ }^{59}$ The commentary goes on to list examples for such practices and explains that

"in some countries private security firms may be contracted to act as prison guards and in that capacity may exercise public powers such as powers of detention and discipline pursuant to a judicial sentence or to prison regulations. Private or Stateowned airlines may have delegated to them certain powers in relation to immigration control or quarantine." 60

Some scholars argue that the term 'empowered by law' should refer to explicit national legislations. Davitti for example asserts that

"Such powers, however, will only be provided by national prison regulations or pertain to the enforcement of a judicial sentence. PMSC's transnational activities, instead, are usually regulated by contractual agreements stipulated between the state and the company itself. Such contracts will usually not be a sufficient legal instrument to empower the PMSC with governmental authority." ${ }^{\prime 61}$

She bases her argument on the claim that these services are not necessarily regulated by law, e.g. immigration detention is usually administrative in nature, therefore regulations pertaining to prisons and detention centers within the criminal justice system will not apply to them. ${ }^{62}$

Conversely, others such as Tonkin argue that the notion 'empowered by law' refers not to a specific legislation empowering PMSCs to undertake certain functions of governmental authority, but a legal framework allowing the outsourcing of such

\footnotetext{
57 Article 5 DARSIWA

58 Draft articles on Responsibility of States for Internationally Wrongful Acts, with commentaries, Yearbook of the International Law Commission, vol. II, Part 2, 2001, p. 42, para 1

59 Draft articles on Responsibility of States for Internationally Wrongful Acts, with commentaries, op. cit., note 58 , p. 43 , para 2

60 ibid.

61 Davitti, op. cit., note 21, p. 17

62 ibid.
} 
activities to the private sector would be sufficient. ${ }^{63}$ Cameron and Chetail take a similar position, arguing that even the French version of the commentaries support this interpretation. ${ }^{64}$ The co-authors also go one step further, claiming that "a state cannot invoke the lacunae of its domestic order to escape the reality of the fact that it has outsourced governmental functions relevant to its international obligations." ${ }^{65}$ Consequently, the state would be liable for the conduct of a PMSCs merely by contracting with the company. This position can be supported by the Yeager case before the Iran-US Claims Tribunal and the International Court of Justice in the Armed Activities on the Territory of the Congo case. ${ }^{66}$ This contribution therefore asserts that in lack of the customary international law nature of the criterion 'empowered by law ${ }^{67}$ in Article 5 of DARSIWA, a contract in itself is sufficient to attribute the conduct of a PMSC to a state, in case the outsourcing pertains to exercising governmental authority. ${ }^{68}$ The final question that needs to be answered is what exactly are the elements of governmental authority, the exercise of which will lead to attribution? As the commentary refers to guarding prisons and detention centers and immigration control or quarantine, ${ }^{69}$ this paper claims that the conduct of PMSCs acting in migration and/or border control, contracted for this purpose by a state should be attributable to the state. ${ }^{70}$ The same should apply mutatis mutandis to international organizations such as the EU. In case the Union contracts a PMSC specifically for exercising such functions, the conduct of the private company would indeed be attributable to the European Union. It is important to note that this attributional link is automatic, for it does not require a case-by-case analysis of control over the PMSC, the existence of the contract is sufficient. ${ }^{71}$

63 Tonkin, op. cit., note 56, p. 111

64 Cameron; Chetail, op. cit., note 10, p. 168

$65 \quad$ ibid. $\mathrm{p} 169$

${ }_{66} i$ ibid. It needs to be noted however, that the ICJ refers to Article 5 DARSIWA rather briefly claiming that „[i]n the view of the Court, the conduct of the MLC was not [...] that of an entity exercising elements of governmental authority on its behalf (Art. 5)." Armed Activities on the Territory of the Congo, op. cit., note 48, p. 226. para 160. The notion of 'empowered by law' is clearly missing however it is far from conclusive to claim that leaving out such a criterion is intentional, for the the ICJ has left out numerous criteria from another attrtibution test in the Genocide case. See Kis Kelemen; van Rij, op. cit., note 52, p. 107

67 Cameron; Chetail, op. cit., note 10, p. 170

68 Kis Kelemen; van Rij, op. cit., note 52, p. 102

69 Draft articles on Responsibility of States for Internationally Wrongful Acts, with commentaries, $o p$. cit., note 58, p. 43 para 2

70 Kis Kelemen; van Rij, op. cit., note 52, p. 104

71 ibid. 
Having regard to Article 7 of DARSIWA, Article 6 and 8 of DARIO also capture the problem of excess of authority or contravention of instructions. DARIO stipulates in the general rule of attribution that equating occurs only when the conduct is in the performance of functions of the international organization. ${ }^{72}$ Acts committed in private capacity therefore will not be attributable to the international organization. ${ }^{73}$ Virtually the same is enshrined in Article 7 of DARSIWA requiring acting 'in that capacity' for attribution. ${ }^{74}$ This is further reinforced and supplemented by Article 8 of DARIO, which states that

"[t]he conduct of an organ or agent of an international organization shall be considered an act of that organization under international law if the organ or agent acts in an official capacity and within the overall functions of that organization, even if the conduct exceeds the authority of that organ or agent or contravenes instructions." 75

The notion of 'official capacity' is equivalent to 'in that capacity' for the purposes of attribution. ${ }^{76}$ Therefore international organizations such as the EU should bear responsibility for ultra vires actions as well. ${ }^{77}$

The last attributional tie, that demands an examination is instructions, or direction and control pursuant to the commentary to DARIO as "[s]hould persons or groups of persons act under the instructions, or the direction or control, of an international organization, they would have to be regarded as agents according to the definition given in subparagraph $(d)$ of article 2." ${ }^{78}$

'Direction and control' also appears as a separate article in DARSIWA. Article 8 of DARSIWA stipulates that

$72 \quad$ Article 6 DARIO

73 Draft articles on the responsibility of international organizations, with commentaries, op. cit., note 35 , pp. $55-56$, para 7

74 Article 7 DARSIWA ,The conduct of an organ of a State or of a person or entity empowered to exercise elements of the governmental authority shall be considered an act of the State under international law if the organ, person or entity acts in that capacity, even if it exceeds its authority or contravenes instructions."

75 Article 8 DARIO

76 Draft articles on the responsibility of international organizations, with commentaries, op. cit., note 35, p. 60 , para 4

77 Draft articles on the responsibility of international organizations, with commentaries, op. cit., note 35, p. 61 ,

78 Draft articles on the responsibility of international organizations, with commentaries, op. cit., note 35, p. 56 , para 11 
" $[\mathrm{t}]$ he conduct of a person or group of persons shall be considered an act of a State under international law if the person or group of persons is in fact acting on the instructions of, or under the direction or control of, that State in carrying out the conduct." 79

Sometimes 'direction and control' is mixed up with de facto state organs. ${ }^{80}$ The origin of this confusion might be traced back to the Tadic case before the International Criminal Tribunal for the former Yugoslavia, where the Tribunal applied the 'overall control' test in order to attribute the conduct of private entities to a state. ${ }^{81}$ However this position was criticized not only by the International Court of Justice in the Genocide case ${ }^{82}$ but by many commentators as well..$^{83}$ The correct test to be applied for de facto state organs-as it was posited above-is the 'complete dependency' test, while for 'direction and control', the existence of 'effective control' should be examined on a case-by-case basis. The latter test is more permissive than the former. ${ }^{84}$

The commentary to DARSIWA lists three disjunctive criteria for attribution based on Article 8: instruction, direction and control. If one of these links can be proven, the conduct in question might be equated with the state. ${ }^{85}$ Under instructions, one might understand a decision of state to commit an internationally wrongful act, the implementation of which is the responsibility of a private entity. ${ }^{86}$ For instructions to occur, a clear manifestation of the will of the state has to be shown, which was famously denoted by the International Court of Justice in the United

79 Article 8 DARSIWA

80 See Cameron; Chetail, op. cit., note 10, pp. 204 - 205. Cassese, A., The Nicaragua and Tadic Tests Revisited in Light of the ICJ Judgment on Genocide in Bosnia, The European Journal of International Law, vol. 18 , no. 4, 2007, p. 650

81 Prosecutor v. Duško Tadić, Appeals Chamber Judgment of 15 July 1999, para. 120 and 131. A similar but even more permissive link was proposed by Griebel and Plücken as the 'substantial involvment' test. See Griebel, J.; Plücken, M., New Developments Regarding the Rules of Attribution? The International Court of Justice's Decision in Bosnia v Serbia, Leiden Journal of International Law, vol. 21, no. 3, 2008, pp. $619-620$

82 Application of the Convention on the Prevention and Punishment of the Crime of Genocide (Bosnia and Herzegovina v. Serbia and Montenegro), Judgment, I.C.J. Reports 2007, p. 43, on pp. 170 - 171. paras. $402-406$.

83 Kajtár, G., A nem állami szereplök elleni önvédelem a nemzetközi jogban, ELTE Kiadó, Budapest 2015, pp. 217 -219. 22. Milanović, M., State Responsibility for Acts of Non-state Actors: A Comment on Griebel and Plücken, Leiden Journal of International Law, vol. 22, no. 2, 2009, pp. 318 - 319. and pp. 321 322

84 Kis Kelemen; van Rij, op. cit., note 52, p. 105. Application of the Convention on the Prevention and Punishment of the Crime of Genocide, op. cit., note 82, p. 169. para. 400

85 Draft articles on Responsibility of States for Internationally Wrongful Acts, with commentaries, $o p$. cit., note 58, p. 48, para. 7

86 Cameron; Chetail, op. cit., note 10, p. 205 
States Diplomatic and Consular Staff in Tehran case. ${ }^{87}$ Davitti argues that the wording of a contract or the fact that a PMSC acted upon the instruction of a state might be enough to attribute private conduct to a state, although she accepts that "[h] uman rights abuses or other wrongful conduct generally fall outside of the substantive scope of such contractual arrangements, so it would be difficult, based on the contract alone, to prove that the PMSC acted under the instruction of the hiring state." 88

I completely agree with this position. ${ }^{89}$ Virtually the same conclusion can be drawn for 'direction and control', where 'effective control' is a requirement for attribution. This test was developed by the International Court of Justice in the Nicaragua case,${ }^{90}$ later reinforced in the Genocide case. ${ }^{91}$ It needs to be pointed out that either specific instructions or the 'effective control' in every single operation must be proven to equate private conduct with a state. ${ }^{92}$ Consequently, this attribution link is virtually non-provable, ${ }^{93}$ leaving it an incidental tie to the state. ${ }^{94}$ Ultra vires actions or conduct which contravenes instruction are usually also attributable to a state, in case the private entity is under the effective control of a state. ${ }^{95}$ In the absence of effective control, no attribution should occur, since a lawful instruction would never result in attribution for internationally wrongful conduct.

Within the scope of 'direction and control', ownership of a private entity also deserves attention. According to the commentary to DARSIWA, the fact that a state has created a corporation would not in itself equate the conduct of such an organization with that of the state, but utilizing the ownership to influence decisions

87 United States Diplomatic and Consular Staff in Tehran, Judgment, I. C. J. Reports 1980, p. 3, on p. 30. para. 59. "In the view of the Court, however, it would be going too far to interpret such general declarations of the Ayatollah Khomeini to the people or students of Iran as amounting to an authorization from the State to undertake the specific operation of invading and seizing the United States Embassy. To do so would, indeed, conflict with the assertions of the militants themselves who are reported to have claimed credit for having devised and carried out the plan to occupy the Embassy."

88 Davitti, op. cit., note 21, p. 17

89 Kis Kelemen; van Rij, op. cit., note 52, p. 106

90 Military and Paramilitary Activities in and against Nicaragua (Nicaragua v. United States of America), Merits, Judgment, I.C.J. Reports 1986, p. 14, on p. 55. para. 115

91 Application of the Convention on the Prevention and Punishment of the Crime of Genocide, op. cit., note 82 , p. 169 . para. 400

92 ibid.

93 Cameron; Chetail, op. cit., note 10, p. 216

94 Kis Kelemen; van Rij, op. cit., note 52, p. 107

95 Draft articles on Responsibility of States for Internationally Wrongful Acts, with commentaries, $o p$. cit., note 58 , p. 48 , para 8 
of the corporations could lead to attribution..${ }^{96}$ In case a state has created a private entity and controls it without meaningful independence on the side of the company, it could be argued that attribution might occur through the de facto state organ rule due to 'complete dependency'. Since 'effective control' requires a lower level of dependency, it might be argued that a state using its controlling interest in a company for specific operations may be enough to equate those actions with action by the state. ${ }^{97}$ The same should be true mutatis mutandis for international organizations as well. The only divergence might arise for instructions where the international organization might be responsible for lawful instructions as well, if the agent in its official capacity contravened instructions. ${ }^{98}$ The reason behind the difference would be the lack of a separate article on instruction, direction and control in DARIO, which could have addressed this situation.

Based on the above, the following conclusion might be drawn for the European Union and PMSCs: the conduct of a PMSC might be equated with the conduct of the EU in case the former exercises elements of governmental authority via a contract concluded between the corporation and the Union. In order to be able to establish such a link, the contract should refer to elements of governmental authority such as operating detention facilities, providing services for migration control or participating in border control activities. Theoretically, attribution might also occur if the EU would instruct PMSCs to commit internationally wrongful acts such as human rights violations or if the PMSC would, under the effective control of the Union violate international law in a specific situation. In Part III, this contribution will examine the publicly available tenders and framework contracts concluded between the EU and a PMSC, then it will investigate whether such an attribution link might be established. In turn however the paper analyses positive obligations stemming from international law, the violation of which might also give way to the responsibility of international organizations such as the EU for the conduct of private entities.

\section{EU CONTRACTS WITH PMSCS WITHIN MIGRATION AND BORDER CONTROL}

As it was noted by Davitti, EASO has concluded two contracts with G4S for two purposes: security services in Greece and provision of security services for EASO premises in Malta. ${ }^{99}$ Concerning the contract for security services in Greece al-

\footnotetext{
$96 \quad$ ibid. para. 6

97 Kis Kelemen; van Rij, op. cit., note 52, pp. 107. and 110

98 Article 8 DARIO

99 Davitti, op. cit., note 6, pp. 41 and 50
} 
leged human rights violations has already occurred. ${ }^{100}$ The present paper in turn investigates these contracts and the possible human rights violations in connection with it.

It has to be noted that the two abovementioned contracts are indeed listed on one of the EASO contract lists awarded in 2017 under reference number EASO/2017/453 and EASO/2017/516. ${ }^{101}$ One open call for tender for security services in Cyprus for the first quarter of 2020 was also identifiable. ${ }^{102}$ The present author has requested access to the contracts on hand and the details on the open call for tender. In its response, the EASO granted access to tender specifications and draft framework contracts for the two already concluded contracts, but rejected access to the specific contract and the open call for tender due to the demand of "undistorted competition" and the "protection of commercial interests of a natural or legal person including intellectual property." 103

\subsection{Provision of security services in Greece}

The first contract examined is the one concerning the provision of security services in Greece, most prominently in the hotspots operated by EASO for registration and screening of irregular migrants and asylum support. ${ }^{104}$ According to the tender specifications, the services required are:

- "Surveillance and patrolling in EASO operations in Lesvos, Chios, Samos, Kos, Leros, Athens, Thessaloniki, and Alexandroupoli;

- Access control of visitors and applicants for international protection to the EASO premises;

- The surveillance and safeguarding of assets within the premises." 105

100 Lethbridge, $o p$. cit., note 19

101 List of contracts awarded by the European Asylum Support Office in 2017 in accordance with Article 124 of the Commission delegated regulation (EU) No 2462/2015 of 30 October 2015 on the rules of application of Regulation (EU, Euratom) No 1929/2015 of the Financial Regulation applicable to the general budget of the Union [https://easo.europa.eu/sites/default/files/EASO-contracts-awarded-2017.pdf], Accessed 13 April 2020. Both contracts had been concluded between G4S and EASO, although two different companies were used for concluding the contracts: G4S Security Services Ltd. for Malta and G4S Secure Solutions S.A. for Greece

102 EASO Procurement plan 2020, [https://www.easo.europa.eu/sites/default/files/procurements/procurement-plan-2020.pdf], Accessed 13 April 2020, p. 15, item No. 30

103 Response of the EASO. On file with the Author

104 EASO Hotspot Operating Plan to Greece, EASO/COS/2015/677, [https://www.easo.europa.eu/sites/ default/files/20150930\%20EASO\%20Hotspot\%20OP\%20Greece.pdf], Accessed 13 April 2020

105 EASO/2016/453 tender specifications, para. 1.2 
The tender specifications clarify the tasks that are required from the contractor, which can be assigned to three major groups: guarding services' in working areas; screening of persons entering and exiting the hotspots including asylum seekers as well as possible guests; and monitoring supplied services. ${ }^{106}$ Nothing in the tender specifications indicates that the contractor would exercise elements of governmental authority. The specifications require requesting the assistance and intervention of the Greek authorities in case of suspect actions. ${ }^{107}$

The framework contract is not particularly helpful for the purposes of this paper. It states however that

" $\mathrm{t}]$ he contractor is responsible for the personnel who carry out the services and exercises its authority over its personnel without interference by the contracting authority. The contractor must inform its personnel that:

(a) they may not accept any direct instructions from the contracting authority; and

(b) their participation in providing the services does not result in any employment or contractual relationship with the contracting authority" 108

and that

"[ $t]$ he contracting authority is not liable for any damage or loss caused by the contractor, including any damage or loss to third parties during or as a consequence of implementation of the FWC." 109

Both provisions intend to make it more difficult to prove effective control over the PMSC contracted and to limit the liability of EASO in connection with the implementation of the contract.

\subsection{Provision of security services for EASO premises in Malta}

The second contract is a simpler one concerning the provision of security services for EASO premises in Malta. The tasks required by the contractor are various, but the most relevant for the purpose of the present contribution would be the surveillance and protection of EASO premises and staff, and reception and access

\footnotetext{
106 ibid. para. 1.3

107 ibid. para. 1.3.A.3, and p. 5

108 EASO/2016/453 draft framework contract, para. II.4.7

109 ibid, para. II.6.1. FWC means framework contract within this quote
} 
control. ${ }^{110}$ Similarly to the Greek contract, nothing in the tender specifications indicate that the contractor would exercise elements of governmental authority in this case and the draft framework contract also contains the above-mentioned articles with identical wording. ${ }^{111}$

\subsection{Alleged interference with rights of asylum seekers}

A number of reports published by various human rights organizations refer to a legal aid organization, which has sued EASO for preventing migrants from accessing certain areas, such as the EASO office, ultimately hampering access to the asylum application process. It has been argued that G4S is assisting EASO in the infringements. ${ }^{12}$ Also a number of Members of the European Parliament from the Green Party have asked questions regarding this lawsuit in the European Parliament, among others regarding the contractual relationship between G4S and EASO:

"What is the role of, and what are the exact tasks being carried out on behalf of EASO by, the private company G4S, which has been awarded a direct employment contract by EASO to offer services within a public institution?"113

The Commission, in its answer delivered by Migration, Home Affairs and Citizenship Commissioner Dimitris Avramopoulos articulated that

"The Hellenic Police and Army have the responsibility for security in the camps. To ensure secure working conditions, the European Asylum Support Office (EASO) in agreement with the Hellenic Police, engaged a security company, G4S, which screens all who enter the interview area. Given the urgency, EASO used the framework Contract of the Commission Representation in Athens as a basis for the contract." 114

It is very interesting however that there is no trace of such a lawsuit in the database of the Court of Justice of the European Union, which would have exclusive

\footnotetext{
$110 \quad$ EASO/2017/516 tender specifications, pp. 6 - 7

111 EASO/2017/516 draft framework contract, para. II.4.7. and II.6.1

112 Arbogast, L., Migrant Detention in the European Union: A Thriving Business, Outsourcing and Privatisation of Migrant Detention, Migreurop, 2016, [https:/www.migreurop.org/IMG/pdf/migrant-detention-eu-en.pdf], Accessed 13 April 2020, p. 40

113 Question for written answer E-005528-16 to the Commission [https://www.europarl.europa.eu/doceo/document/E-8-2016-005528_EN.html], Accessed 13 April 2020

114 Answer given by Mr Avramopoulos on behalf of the Commission E-005528/2016 [https://www.europarl.europa.eu/doceo/document/E-8-2016-005528-ASW_EN.html], Accessed 13 April 2020
} 
jurisdiction to deal with claims against an EU agency. ${ }^{115}$ The answer on the other hand reinforces the findings above, that G4S does not play a significant role in processing asylum applications. The security in the camps is not even provided by a PMSC but a Member State, namely Greece.

It has to be noted however that PMSCs, more specifically G4S plays an important role in providing security services for the EU within Europe and even for actions in the framework of the Common Foreign and Security Policy. ${ }^{116}$ In spite of this, there is no evidence that would suggest that PMSCs play a major role in implementing the European Agenda on Migration, at least at the Union level. The contracts that are currently available for research are common security services which are necessary for the uninterrupted and effective operations of any public institution. In order to be thorough, the present author had surveyed Frontex as well, whether they have similar contracts to EASO, but the agency in its response clarified that they do not use PMSCs for border control activities.

"Registration and identification of the incoming migrants as well as surveillance along EU's external land borders is performed exclusively by border guards coming from various EU Member States, while border surveillance at sea and SAR is performed by coast guard officers and these tasks are not outsourced to private security companies." 117

Frontex as a rule does not use private companies for building security either with the exception of the office in Catania. ${ }^{118}$

\section{CONCLUSIONS}

This contribution examined questions of responsibility for an alleged outsourcing of migration and border control related activities of the European Union to PMSCs. While there are a number of ways to attribute the conduct of private en-

115 Article 268 and 340 TFEU For EU agencies. See Duić, D., EU agencies procedure - is there a possibility for an inter-agency and cross-sectoral approach in matters of security, in: Duić, D.; Petrašević, T., (eds.), EU and Comparative Law Issues and Challenges Series (ECLIC I) - Procedural aspects of EU law, Osijek, 2017, pp. $322-324$

116 Nielson, N., G4S: the EU's preferred security contractor, EU observer [https://euobserver.com/institutional/147608], Accessed 13 April 2020

117 Response of Frontex on file with the Author. For an analysis of these operations see Fink, M., A 'Blind Spot' in the framework of international responsibility? Third Party Responsibility for Human Rights Violations: The Case of Frontex, in: Gammeltoft-Hansen, T.; Vedsted-Hansen, J. (eds), Human Rights and the Dark Side of Globalisation: Transnational Law Enforcement, Routledge, London, 2016, pp. 272 $-293$

118 Security services for EURTF Catania, Italy, Frontex/OP/293/2017/ag, [https://etendering.ted.europa. eu/cft/cft-display.html?cftId=2769], Accessed 13 April 2020 
tities to international organizations, such as exercising elements of governmental authority or effective control over specific operations of private persons, there are inherent difficulties within the procedural aspects of proving such an attributional link.

Turning to the specific issues at hand, there are two contracts concluded between EASO and a PMSC which can be linked to migration control. The subjects of both of these contracts are providing security services for EASO. While the final contracts are unavailable to the public, the tender specifications clearly indicate, that PMSCs do not play a significant role in implementing the European Agenda on Migration, at least on the EU level. Conversely, the services they provide are not unique to migration control, but necessary for the effective operation of EASO. The attribution of the examined conduct is not possible through exercising elements of governmental authority, and proving effective control for a specific operation would also encounter considerable difficulties.

The fact that, at the time this study was conducted, there is no contract in force meeting the above-mentioned criteria does not mean that this will be true for the future as well. As the European Parliament has called for a regulation of private security companies in connection with the Common Foreign and Security Policy, ${ }^{119}$ this paper also stresses a need to regulate the conduct of such private corporations. At a bare minimum, clear guidelines are required as to what kind of companies are eligible for participating in EU tenders, but in the end, a Union level regulation could develop a true accountability regime of PMSCs, and fulfill at least the legislative positive 'obligations' of the European Union in the realm of human rights.

\section{REFERENCES}

\section{BOOKS AND ARTICLES}

1. Bordin, F. L., Reflections of customary international law: the authority of codification conventions and ILC draft articles in international law, International Comparative Law Quarterly, vol. 63, no. 3, 2014, pp. $535-567$

2. Cameron, L.; Chetail, V., Privatizing War - Private Military and Security Companies under Public International Law, Cambridge University Press, Cambridge, New York, 2013

3. Cassese, A., The Nicaragua and Tadic Tests Revisited in Light of the ICJ Judgment on Genocide in Bosnia, The European Journal of International Law, vol. 18, no. 4, 2007, pp. 649 - 668

4. Chalmers, D.; Davies, G.; Monti, G., European Union Law, Second edition, Cambridge University Press, Cambridge, New York, 2010

119 European Parliament resolution of 4 July 2017 on private security companies (2016/2238(INI)) OJ C $334,19.9 .2018$, p. $80-87$ 
5. Crowe, J.; John, A., The Status of Private Military Security Companies in United Nations Peacekeeping Operations under the International Law of Armed Conflict, Melbourne Journal of International Law, vol. 18, no. 1, 2017, pp. $16-44$

6. Davitti, D., Beyond the Governance Gap: Accountability in Privatized Migration Control, German Law Journal, vol. 21, no. 3, 2020, pp. 487 - 505.

7. Davitti, D., The Rise of Private Military and Security Companies in European Union Migration Policies: Implications under the UNGPs, Business and Human Rights Journal, vol. 4, no. 1, 2018, pp. $33-53$

8. del Prado, J. L. G., The Ineffectiveness of the Current Definition of a "Mercenary" in International Humanitarian and Criminal Law, in: Torroja, H. (ed.), Public International Law and Human Rights Violations by Private Military and Security Companies, Springer, Cham, 2017, pp. $59-81$

9. Duić, D., EU agencies procedure - is there a possibility for an inter-agency and cross-sectoral approach in matters of security, in: Duić, D.; Petrašević, T., (eds.), EU and Comparative Law Issues and Challenges Series (ECLIC I) - Procedural aspects of EU law, Osijek, 2017, pp. $322-324$

10. Fink, M., A 'Blind Spot' in the framework of international responsibility? Third Party Responsibility for Human Rights Violations: The Case of Frontex, in: Gammeltoft-Hansen, T.; VedstedHansen, J. (eds), Human Rights and the Dark Side of Globalisation: Transnational Law Enforcement, Routledge, London, 2016, pp. $272-293$

11. Foong, A., The Privatization of War: From Privateers and Mercenaries to Private Military and Security Companies, Asia Pacific Yearbook of International Humanitarian Law, vol. 4, 2008 - 2011, pp. $210-244$

12. Griebel, J.; Plücken, M., New Developments Regarding the Rules of Attribution? The International Court of Justice's Decision in Bosnia v Serbia, Leiden Journal of International Law, vol. 21, no. 3, 2008, pp. $601-622$

13. Holly, G., Transnational Tort and Access to Remedy under the UN Guiding Principles on Business and Human Rights: Kamasaee $v$ Commonwealth, Melbourne Journal of International Law, vol. 19, no. 1, 2018, pp. $52-83$

14. Janaby, M. G., The Legal Regime Applicable to Private Military and Security Company Personnel in Armed Conflicts, Springer, Cham, 2016

15. Kajtár, G., A nem állami szereplök elleni önvédelem a nemzetközi jogban, ELTE Kiadó, Budapest 2015

16. Kis Kelemen, B.; van Rij, J., Private military and security companies on E.U. borders: who will take responsibility for their human rights violations? - A theoretical analysis, in: Kis Kelemen, B.; Mohay, Á., EU justice and home affairs research papers in the context of migration and asylum law, University of Pécs, Pécs, 2019, pp. 95 - 110

17. Laborie, M., Afghanistan and Syria: Nonstate Actors and Their Negative Impact on Human Security, in: Torroja, H. (ed.), Public International Law and Human Rights Violations by Private Military and Security Companies, Springer, Cham, 2017, pp. 7 - 29

18. Lemberg-Pedersen, M., Private security companies and the European borderscapes, in: Gammeltoft-Hansen, T.; Nyberg, N. (eds.), The Migration Industry and the Commercilizations of International Migration, Routledge, London, 2013, pp. 152 - 172 
19. Milanović, M., State Responsibility for Acts of Non-state Actors: A Comment on Griebel and Plücken, Leiden Journal of International Law, vol. 22, no. 2, 2009, pp. 307 - 324

20. Mölder, M., Responsibility of International Organizations - Introducing the ILC's Dario, in: von Bogdandy, A.; Wolfrum, R. (eds.), Max Planck Yearbook of United Nations Law, vol. 16, 2012, pp. $281-328$

21. Sari. A.; Wessel, R. A., International Responsibility for EU Military Operations: Finding the EU's place in the Global Accountability Regime, in: Van Vooren, B.; Blockmans, S.; Wouters, J. (eds), The EU's Role in Global Governance: The Legal Dimension, Oxford University Press, Oxford, 2013, pp. 126 - 141

22. Schmitt, M. N., Humanitarian Law and Direct Participation in Hostilities by Private Contractors or Civilian Employees, Chicago Journal of International Law, vol. 5, no. 2, 2005, pp. $511-546$

23. Szalai, A., A katonai magánvállalatok részvétele és jogállása a fegyveres konfliktusokban, FÖLDrész - Nemzetközi és Európai Jogi Szemle, vol. 3, no. 1 - 2, 2010, pp. 38 - 48

24. Tonkin, H., State Control over Private Military and Security Companies in Armed Conflict, Cambridge University Press, Cambridge, New York, 2011

25. Xenos, D., The Positive Obligations of the State under the European Convention of Human Rights, Routledge, London, New York, 2012

\section{INTERNATIONAL TREATIES}

1. Agreement between the European Union and the Republic of Turkey on the readmission of persons residing without authorization, [2014] OJ L 134, 7.5.2014, p. 3 - 27

\section{EU LAW}

1. Regulation (EU) No 604/2013 of the European Parliament and of the Council of 26 June 2013 establishing the criteria and mechanisms for determining the Member State responsible for examining an application for international protection lodged in one of the Member States by a third-country national or a stateless person [2013] OJ L 180, 29.6.2013, p. 31 $-59$

2. TEU (Lisbon)

3. TFEU (Lisbon)

\section{COURT DECISIONS}

1. Applicability of Article VI, Section 22, of the Convention on the Privileges and Immunities of the United Nations, Advisory Opinion, I.C.J. Reports 1989, p. 177.

2. Application of the Convention on the Prevention and Punishment of the Crime of Genocide (Bosnia and Herzegovina v. Serbia and Montenegro), Judgment, I.C.J. Reports 2007, p. 43.

3. Armed Activities on the Territory of the Congo (Democratic Republic of the Congo v. Uganda), Judgment, I.C.J. Reports 2005, p. 168.

4. Kamasaee v Commonwealth of Australia \& Ors (Approval of settlement) [2017] VSC 537 
5. Military and Paramilitary Activities in and against Nicaragua (Nicaragua v. United States of America). Merits, Judgment. I.C.J. Reports 1986, p. 14.

6. Prosecutor v. Duško Tadić, Appeals Chamber Judgment of 15 July 1999

7. Reparations for injuries suffered in the service of the United Nations, Advisory Opinion: I.C.J. Reports 1949, p. 174.

8. United States Diplomatic and Consular Staff in Tehran, Judgment, I. C. J. Reports 1980, p. 3.

\section{UNITED NATIONS DOCUMENTS}

1. Draft articles on Responsibility of States for Internationally Wrongful Acts, with commentaries, Yearbook of the International Law Commission, Vol. II, Part 2, 2001, pp. 31 - 143

2. Draft articles on the responsibility of international organizations, with commentaries, Yearbook of the International Law Commission, Vol. II, Part 2, 2011, pp. 46 - 105

3. Draft Convention on Private Military and Security Companies (PMSCs) for consideration and action by the Human Rights Council, Report of the Working Group on the use of mercenaries as a means of violating human rights and impeding the exercise of the right of peoples to self-determination, A/HRC/12/25, 5 July 2010

4. Resolution adopted by the General Assembly on 12 December 2001 56/83. Responsibility of States for internationally wrongful acts. (A/RES/56/83)

5. Resolution adopted by the General Assembly on 9 December 2011 66/100. Responsibility of international organizations. (A/RES/66/100)

6. Responsibility of international organizations. Comments and observations received from international organizations dated 14 and 17 February 2011 (A/CN.4/637 and Add.1.)

7. United Nations Guiding Principles on Business and Human Rights: Implementing the United Nations 'Protect, Respect and Remedy' Framework (A/HRC/17/31) adopted by the Human Rights Council on 16 June 2011 as resolution 17/4

\section{WEBSITE REFERENCES}

1. Answer given by Mr Avramopoulos on behalf of the Commission E-005528/2016 [https:// www.europarl.europa.eu/doceo/document/E-8-2016-005528-ASW_EN.html], Accessed 13 April 2020

2. Arbogast, L., Migrant Detention in the European Union: A Thriving Business, Outsourcing and Privatisation of Migrant Detention, Migreurop, 2016, [https:/www.migreurop.org/IMG/ pdf/migrant-detention-eu-en.pdf], Accessed 13 April 2020

3. Beirens H., Cracked Foundation, Uncertain Future - Structural weaknesses in the Common European Asylum System, Migration Policy Institute Europe, [https://www.migrationpolicy. org/sites/default/files/publications/CEAS-StructuralWeaknesses_Final.pdf], Accessed 13 April 2020

4. EASO Hotspot Operating Plan to Greece, EASO/COS/2015/677, [https://www.easo.europa.eu/sites/default/files/20150930\%20EASO\%20Hotspot\%20OP\%20Greece.pdf], Accessed 13 April 2020 
5. EASO Procurement plan 2020, [https://www.easo.europa.eu/sites/default/files/procurements/procurement-plan-2020.pdf], Accessed 13 April 2020

6. Henley J., What is the current state of the migration crisis in Europe? The Guardian, [https:// www.theguardian.com/world/2018/jun/15/what-current-scale-migration-crisis-europe-future-outlook], Accessed 13 April 2020

7. Lethbridge, J., Privatisation of Migration and Refugee Services and Other Forms of State Disengagement, Public Services International [http://www.world-psi.org/en/privatisation-migration-refugee-services-other-forms-state-disengagement], Accessed 13 April 2020

8. List of contracts awarded by the European Asylum Support Office in 2017 in accordance with Article 124 of the Commission delegated regulation (EU) No 2462/2015 of 30 October 2015 on the rules of application of Regulation (EU, Euratom) No 1929/2015 of the Financial Regulation applicable to the general budget of the Union [https://easo.europa.eu/ sites/default/files/EASO-contracts-awarded-2017.pdf], Accessed 13 April 2020

9. Migrant crisis: One million enter Europe in 2015, BBC News, [https://www.bbc.com/news/ world-europe-35158769], Accessed 13 April 2020

10. Nielson, N., G4S: the EU's preferred security contractor, EU observer [https://euobserver.com/ institutional/147608], Accessed 13 April 2020

11. Question for written answer E-005528-16 to the Commission [https:/www.europarl.europa.eu/doceo/document/E-8-2016-005528_EN.html], Accessed 13 April 2020

12. Security services for EURTF Catania, Italy, Frontex/OP/293/2017/ag, [https://etendering. ted.europa.eu/cft/cft-display.html?cftId=2769], Accessed 13 April 2020

13. Wintour P.; Smith H.: Erdoğan in talks with European leaders over refugee cash for Turkey, The Guardian. [https://www.theguardian.com/world/2020/mar/17/erdogan-in-talks-witheuropean-leaders-over-refugee-cash-for-turkey], Accessed 13 April 2020

\section{OTHER SOURCES}

1. Communication from the Commission to the European Parliament, the Council, The European Economic and Social Committee and the Committee of the Regions - A European Agenda on Migration, COM(2015) 240, Brussels, 13 May 2015

2. EASO/2016/453 draft framework contract

3. EASO/2016/453 tender specifications

4. EASO/2017/516 draft framework contract

5. EASO/2017/516 tender specifications

6. European Parliament resolution of 4 July 2017 on private security companies (2016/2238(INI)) OJ C 334, 19.9.2018, p. $80-87$

7. European Parliament: The Role of private security companies (PSCs) in CSDP missions and operations. Directorate-General for External Policies of the Union, Directorate B, Policy Department, 2011

8. International Code of Conduct for Private Security Service Providers, 9 November 2010

9. Response of EASO

10. Response of Frontex 
11. The Montreux Document on pertinent international legal obligations and good practices for States related to operations of private military and security companies during armed conflict, 2008

12. Wallace, S., Case Study on Holding Private Military and Security Companies Accountable for Human Rights Violations, Frame. Work Package No. 7. - Deliverable No. 7.5. 2016 